\title{
Microbiologically induced cable bolt corrosion in underground coal mines
}

\author{
H Chen UNSW Sydney, Australia \\ O Kimyon UNSW Sydney, Australia \\ HL Ramandi UNSW Sydney, Australia \\ B Hebblewhite UNSW Sydney, Australia \\ M Manefield UNSW Sydney, Australia
}

A Crosky UNSW Sydney, Australia

S Saydam UNSW Sydney, Australia

AH Kaksonen Commonwealth Scientific and Industrial Research Organisation, Australia

C Morris Commonwealth Scientific and Industrial Research Organisation, Australia

\begin{abstract}
Corrosion failure is one of the serious concerns with most metal products. In the mining industry, corrosion failure of cable bolts may threaten the safety of operations and cause significant financial losses. In recent years, many cable bolt failures have been reported from several underground coal mines in Australia. Recent studies have shown that the localised environment around the cable bolts (oxygen level, groundwater, bacteria, etc.) has a significant impact on the corrosion behaviour; however, studies on the role of bacteria in the corrosion of underground support systems are still limited. This paper reports on a study of the role of a well-known bacterium in microbiologically induced corrosion of cable bolts. Acidithiobacillus ferrooxidans is found in many underground mines. The cable bolt specimens used in the study were specially designed to simulate the stress level experienced in the in situ mine condition. The specimens were analysed based on their weight loss and morphological features at the end of the study. The results indicated that the involvement of the bacteria in localised corrosion development and biofilm formation on the metal surface was a contributing factor in accelerating the corrosion of the bolt and could lead to catastrophic failure of the bolts in the long term.
\end{abstract}

Keywords: Acidithiobacillus ferrooxidans, cable bolt, corrosion failure, underground mine, safety

\section{Introduction}

In underground mines, cable bolts are commonly used as one of the secondary anchoring systems to stabilise strata. Cable bolts are made of cold-drawn high-carbon steels and generally have greater length and flexibility than conventional rockbolts, enabling anchoring to deeper stable rocks. This has made their application very common in underground mines. However, the high loading condition and the complex geological environment in the mines increase the risk of failure of the bolts, especially corrosion failure.

Corrosion of metal occurs in many industries. About $20 \%$ of all metal corrosion is linked to microbiologically induced corrosion (MIC; Flemming \& Shaule 1994). MIC can be described by the electrochemical corrosion model, in which a microbial colony on a metal surface can act as an electron acceptor and create an electrochemical cell, causing a localised metal dissolution reaction (Videla 2001). Unlike electrochemical corrosion, the MIC process is often difficult to identify due to the complex reactions on the metal surface in the presence of microorganisms (Wang et al. 2014). When the microorganisms are attached to the metal 
surface, the corrosion process can be activated once the bacteria start to colonise and change the localised environment (Little et al. 2007).

Acidithiobacillus ferrooxidans bacterium is known to be involved in MIC, especially in pitting corrosion (Kelly et al. 2000; Moradi et al. 2011). A. ferrooxidans obtains energy from the oxidation of ferrous iron and inorganic sulphur compounds (e.g. pyrite; Temple \& Colmer 1951). Underground coal mines, therefore, can provide ideal environments for $A$. ferrooxidans to grow and cause MIC in steel anchoring systems. According to the preliminary examination of groundwater from an Australian underground coal mine, A. ferrooxidans is one of the most common bacteria in the environment. When pitting corrosion occurs in the cable bolt surface, load carried by the bolt is likely concentrated at the corrosion pits and causes overload fracture. As acidic environments are ideal for the growth of $A$. ferrooxidans, many earlier studies using this species were conducted in low pH (below 3) conditions (Rojas-Chapana \& Tributsch 2001; Suzuki et al. 1990). However, in most of the underground coal mines, the environment is near neutral (Wu et al. 2018). This study was carried out to investigate the likelihood of growth of this bacterium in the near neutral conditions (underground mine condition) and the occurrence of pitting corrosion on the cable bolt surface.

\section{Experimental procedure}

In order to simulate the loading condition of cable bolts in underground mines, coupon specimens were made, as shown in Figure 1. The specimens were made from the central wire of a cable bolt with a diameter of about $6 \mathrm{~mm}$. The coupon was configurated according to the three-point bending method. The distance between two locking rings was $75 \mathrm{~mm}$, and the diameter of the loading pin was about $6 \mathrm{~mm}$. The system was loaded approximately $1,500 \mathrm{MPa}$, which was similar to the load carried by the cable bolt wires during the service.



Figure 1 Cable bolt coupon

A. ferrooxidans strain DSM $14882^{\top}$ used in this experiment was cultured in a medium containing:

- $\left(\mathrm{NH}_{4}\right)_{2} \mathrm{SO}_{4} 132 \mathrm{mg} / \mathrm{L}$.

- $\mathrm{MgCl}_{2} \times 6 \mathrm{H}_{2} \mathrm{O} 53 \mathrm{mg} / \mathrm{L}$.

- $\mathrm{KH}_{2} \mathrm{PO}_{4} 27 \mathrm{mg} / \mathrm{L}$.

- $\mathrm{CaCl}_{2} \times 2 \mathrm{H}_{2} \mathrm{O} 147 \mathrm{mg} / \mathrm{L}$.

- $\mathrm{FeSO}_{4} \times 7 \mathrm{H}_{2} \mathrm{O} 20 \mathrm{~g}$.

- $0.25 \mathrm{~N} \mathrm{H}_{2} \mathrm{SO}_{4} 50 \mathrm{~mL}$.

The $\mathrm{pH}$ of the medium was adjusted to 1.8 using $\mathrm{H}_{2} \mathrm{SO}_{4}$. The bacteria were then grown in this medium for about two weeks before the experiment. When the experiment started, the coupons were placed into a $1 \mathrm{~L}$ bottle and filled with groundwater collected from an underground coal mine located in New South Wales, Australia. The chemical composition of the water is listed in Table 1 . A $50 \mathrm{~mL}$ aliquot of bacterial culture was added into the bottle, and the bottle was sealed by a sponge lid to allow oxygen into the system. Three inoculated bottles and three control bottles without bacterial inoculum were prepared. The bottles were incubated in a temperature-controlled room, at $20^{\circ} \mathrm{C}$, to simulate the temperature in an underground mine. 
Table 1 Chemical compositions of the groundwater

\begin{tabular}{ll}
\hline Chemical & $\mathrm{mg} / \mathrm{I}$ \\
\hline $\mathrm{Ca}^{2+}$ & 1.37 \\
$\mathrm{~K}^{+}$ & 5.32 \\
$\mathrm{Mg}^{2+}$ & 0.79 \\
$\mathrm{Na}^{+}$ & 276 \\
$\mathrm{Cl}^{-}$ & 4.8 \\
$\mathrm{SO}_{4}{ }^{2-}$ & 58.3 \\
$\mathrm{pH}$ & 7.5 \\
\hline
\end{tabular}

The experiment was conducted for 180 days, and then each coupon was examined. In order to determine whether the bacteria had colonised steel surfaces, a fixation process was conducted immediately after the removal of coupons from the bottles in order to preserve the cells for imaging. The fixative solution was prepared as $1 \mathrm{~mL}$ of $25 \%$ glutaraldhyde, $5 \mathrm{~mL}$ of $0.2 \mathrm{M}$ sodium cacodylate buffer and $4 \mathrm{~mL}$ MilliQ water. Each coupon was immersed in the solution at $4{ }^{\circ} \mathrm{C}$ overnight and washed with $0.1 \mathrm{M}$ sodium cacodylate buffer for two minutes. Then, the coupons were dehydrated using ethanol from $30 \%$ to $100 \%$ repeatedly in the biowave and left to dry overnight. Once the fixation process was completed, each coupon was examined via a scanning electron microscope (SEM) at the University of New South Wales Mark Wainwright Analytical Centre. After SEM analysis of the bacteria, coupons were washed with Ajax inhibited hydrochloric acid to remove corrosion products on the steel surface. Each coupon was weighted after cleaning to measure weight loss and then examined using an optical microscope (OM) and SEM to characterise the surface morphology.

\section{Results and discussion}

The presence of bacteria was observed on the surface of the steel immersed in the medium containing $A$. ferrooxidans. The SEM image of the bacteria on the steel surface, shown in Figure 2, shows $A$. ferrooxidans formed a cluster with a length of $\sim 10 \mu \mathrm{m}$. The colonisation of the steel surface by the bacteria can lead to the formation of biofilm, which can significantly alter the localised environment and cause severe corrosion, such as pitting. The corrosion products formed on the metal surface shown in Figure 2 were already starting to crack. The unstable passive layer can, in turn, allow the bacteria to reach closer to the cable metal surface and accelerate the localised corrosion process. The detection of a bacterial cluster on the specimen surface indicated that $A$. ferrooxidans could attach to the steel surface in the near neutral environment. However, the relatively high $\mathrm{pH}$ (7.5) condition compared with their preferred environment, which is below 3, may slow down the growth of the bacteria and MIC.

To determine the degree of damage by the bacteria, the treated coupons (immersed in groundwater that contained bacteria) and the reference coupons (immersed in groundwater only) were cleaned and weighed. The weight loss of each coupon is shown in Table 2. The results show the average initial and final weights of three coupons in each treatment. No significant difference was seen between the coupons immersed in bacterial solution (Treatment 2) and those with the groundwater only (Treatment 1). The difference in weight loss was approximately $0.1 \%$, which means in the near neutral environment, $A$. ferrooxidans cannot significantly accelerate the corrosion rate of steel in the time frame of 180 days. Unlike their vigorous activity in low $\mathrm{pH}$ conditions, which can increase the corrosion rate up to six times (Wang et al. 2014), the near neutral environment seemed to inhibit the general corrosion by $A$. ferrooxidans. However, in many of the reported corrosion failure incidents, general corrosion has only a very minor impact on the premature failure of steel structures. Pitting and localised corrosion are usually considered to be the regions of concentration for the stress and initiation of cracks, which then can lead to catastrophic failures. 


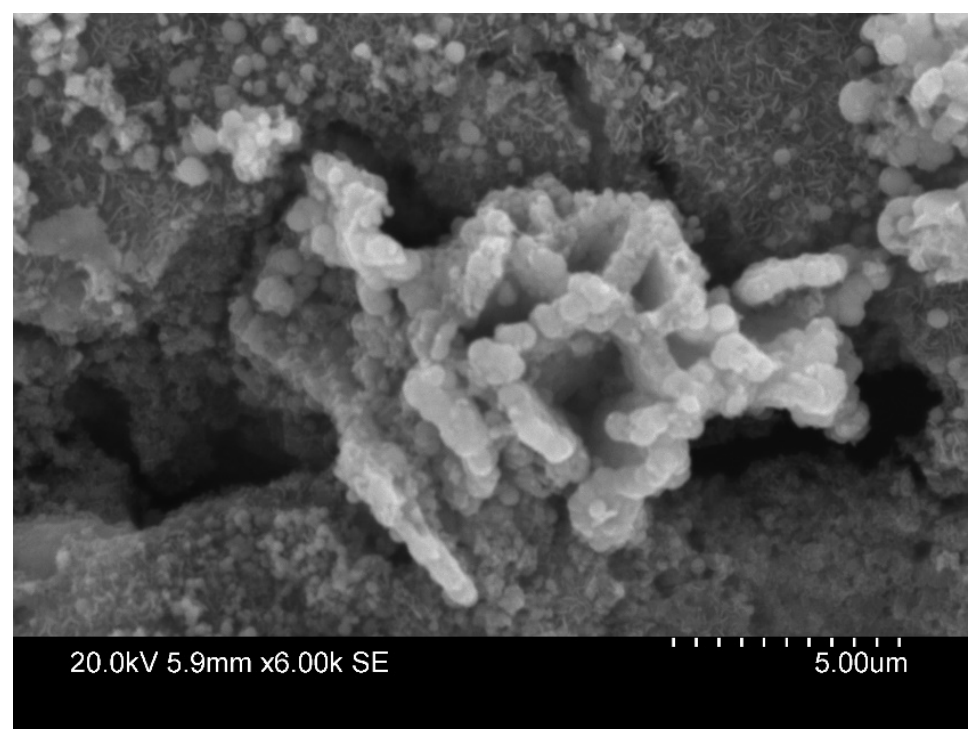

Figure 2 Bacteria on the steel surface

Table 2 Weight loss of coupons

\begin{tabular}{llll}
\hline Treatment & $\begin{array}{l}\text { Average initial } \\
\text { weight }(\mathbf{g})\end{array}$ & $\begin{array}{l}\text { Average final } \\
\text { weight } \mathbf{( g )}\end{array}$ & $\begin{array}{l}\text { Average } \\
\text { weight loss \% }\end{array}$ \\
\hline 1 (no bacteria) & 116.78 & 114.17 & 2.23 \\
2 (with bacteria) & 115.76 & 113.04 & 2.35 \\
\hline
\end{tabular}

Images from the OM and SEM were used to examine the surface morphology of coupons in different treatments to identify any pitting caused by A. ferrooxidans. The OM images of coupons from both treatments are shown in Figure 3. Figure 3(a) shows the specimen's surface in Treatment 1 (groundwater only). The surface is generally smooth, and no obvious localised corrosion is seen. Figure $3(\mathrm{~b})$ shows the specimen in Treatment 2 (containing bacteria). Localised corrosion can be observed the top of the image with a diameter of $\sim 1 \mathrm{~mm}$. The localised corrosion was likely caused by the attachment of bacteria and a MIC process. The OM images from the specimen surface distinguished the impact of $A$. ferrooxidans on the steel surface.

Other than localised corrosion, small pitting on steel surfaces can cause premature failure. The pitting corrosion was usually much smaller than the localised corrosion, as seen in Figure 3(b), but had a sharper tip at the bottom of the corrosion pit. The corrosion pit can act as a small notch to concentrate stress and cause failure when loaded. The SEM examination of specimen surfaces was conducted to determine whether pitting corrosion had occurred. Figure 4 shows the SEM images of the specimens after different treatments. The surface morphology of the specimen from Treatment 1 without bacteria was relatively smooth, and no obvious corrosion pits were observed (Figure 4[a]). Several corrosion pits with the size ranging from $20 \mu \mathrm{m}$ to $100 \mu \mathrm{m}$ were found on the specimen surface after Treatment 2 with bacteria (Figure $4[b])$. The SEM results were aligned with the OM images, showing that the pitting corrosion only occurred on the specimen in Treatment 2 as a result of the MIC process. Overall, both the OM and SEM analysis results indicated that although $A$. ferrooxidans had not accelerated the general corrosion of steel, it had caused localised corrosion and pitting corrosion on the steel surface, which are both regarded as threats to the steel integrity and performance. 


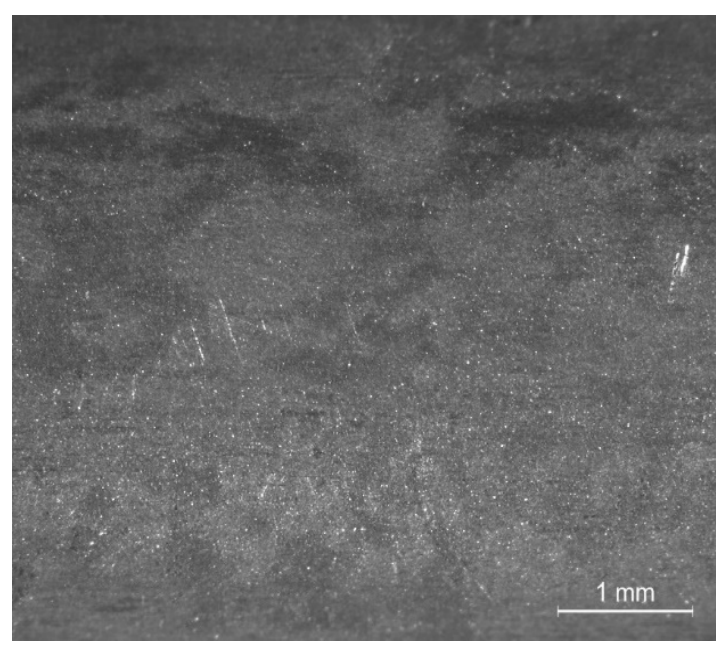

(a)

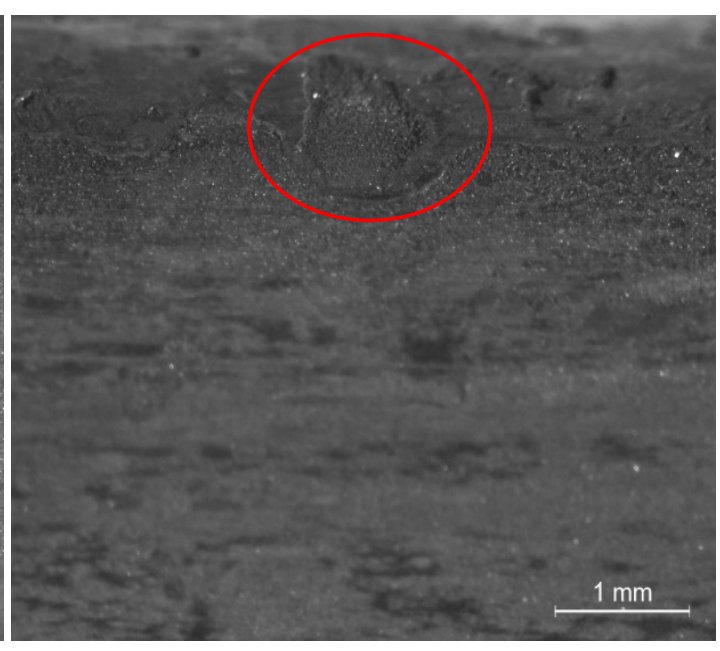

(b)

Figure 3 Macroscope images from the specimen surface: (a) Treatment 1 without bacteria; (b) Treatment 2 with bacteria

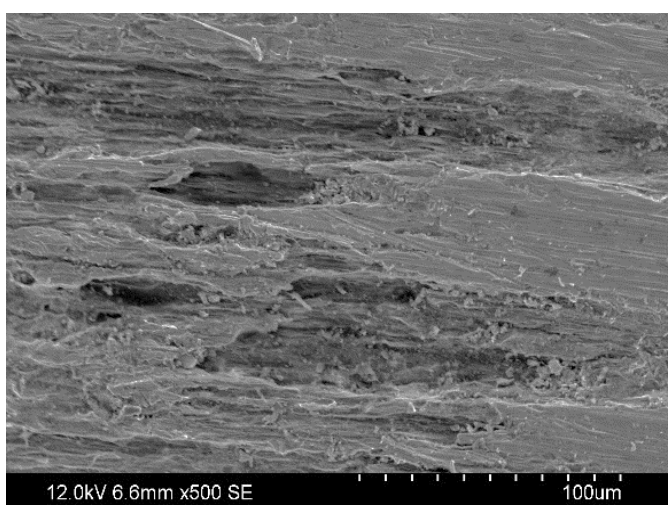

(a)

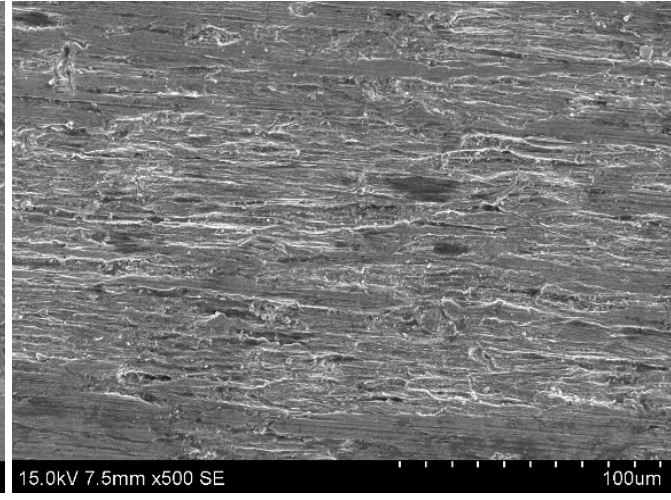

(b)

Figure 4 SEM images from the specimen surface: (a) Treatment 1 without bacteria; (b) Treatment 2 with bacteria

\section{Conclusion}

In this study, it was shown that $A$. ferrooxidans could attach to steel coupons in the near neutral condition, which generally occurs in underground mines. In the near neutral environment, it is less likely that $A$. ferrooxidans alters the corrosion rate significantly; however, MIC can still occur on the metal surface and cause localised corrosion and pitting corrosion. Hence, the development of techniques for preventing damage from $A$. ferrooxidans to the cable bolts in underground mines is recommended.

\section{Acknowledgement}

This research was funded by the Australian Research Council Linkage Projects 140100153 supported by Jennmar Australia Pty Ltd, Glencore Coal Pty Ltd, Illawarra Coal Holdings Pty Ltd, Springvale Coal Pty Ltd and Anglo Operations Proprietary Ltd.

\section{References}

Flemming, H-C \& Shaule, G 1994, 'Microbial deterioration of materials - biofilm and biofouling: Biofouling (Mikrobielle Werkstoffzerstö rung e Biofilm und Biofouling: biofouling), Materials and Corrosion, vol. 45, January, pp. 29-39. 
Kelly, DP \& Wood, AP 2000, 'Reclassification of some species of Thiobacillus to the newly designated genera Acidithiobacillus gen. nov., Halothiobacillus gen. nov. and Thermithiobacillus gen. nov', International Journal of Systematic and Evolutionary Microbiology, vol. 50, pp. 511-516.

Little, BJ, Mansfeld, FB, Arps, PJ \& Earthman, JC 2007, 'Microbiologically Influenced Corrosion', Encyclopedia of Electrochemistry, Wiley Online Library.

Moradi, M, Duan, J, Ashassi-Sorkhabi, H \& Luan, X 2011, 'De-alloying of 316 stainless steel in the presence of a mixture of metal-oxidizing bacteria', Corrosion Science, vol. 53, pp. 4282-4290.

Rojas-Chapana, J \& Tributsch, H 2001, 'Biochemistry of sulfur extraction in bio-corrosion of pyrite by Thiobacillus ferrooxidans' Hydrometallurgy, vol. 59, pp. 291-300.

Suzuki, I, Takeuchi, TL, Yuthasastrakosol, TD \& Oh, JK 1990, 'Ferrous iron and sulfur oxidation and ferric iron reduction activities of Thiobacillus ferrooxidans are affected by growth on ferrous iron, sulfur, or a sulfide ore', Applied and Environmental Microbiology, vol. 56, pp. 1620-1626.

Temple, KL \& Colmer, AR 1951, 'The autotrophic oxidation of iron by a new bacterium: Thiobacillus ferrooxidans', Journal of Bacteriology, vol. 62, p. 605.

Videla, HA 2001, 'Microbially induced corrosion: An updated overview', International Biodeterioration \& Biodegradation, vol. 48, pp. 176-201.

Wang, H, Ju, L-K, Castaneda, H, Cheng, G \& Newby, B-MZ 2014, 'Corrosion of carbon steel C1010 in the presence of iron oxidizing bacteria Acidithiobacillus ferrooxidans', Corrosion Science, vol. 89, pp. 250-257.

Wu, S Chen, H, Craig, P, Ramandi, HL, Timms, W, Hagan, PC, ... \& Saydam, S 2018, 'An experimental framework for simulating stress corrosion cracking in cable bolts', Tunnelling and Underground Space Technology, vol. 76, pp. 121-132. 